\title{
Blog or Slide? Using Appropriate Media to Enhance the Students' Ability in Writing an English Research Proposal based on Their Reasoning Level
}

\author{
Yusti Arini \\ Institut Agama Islam Negeri Surakarta, Jakarta
}

Corresponding Author: Yusti Arini, $\otimes$ arinivirgo29@gmail.com

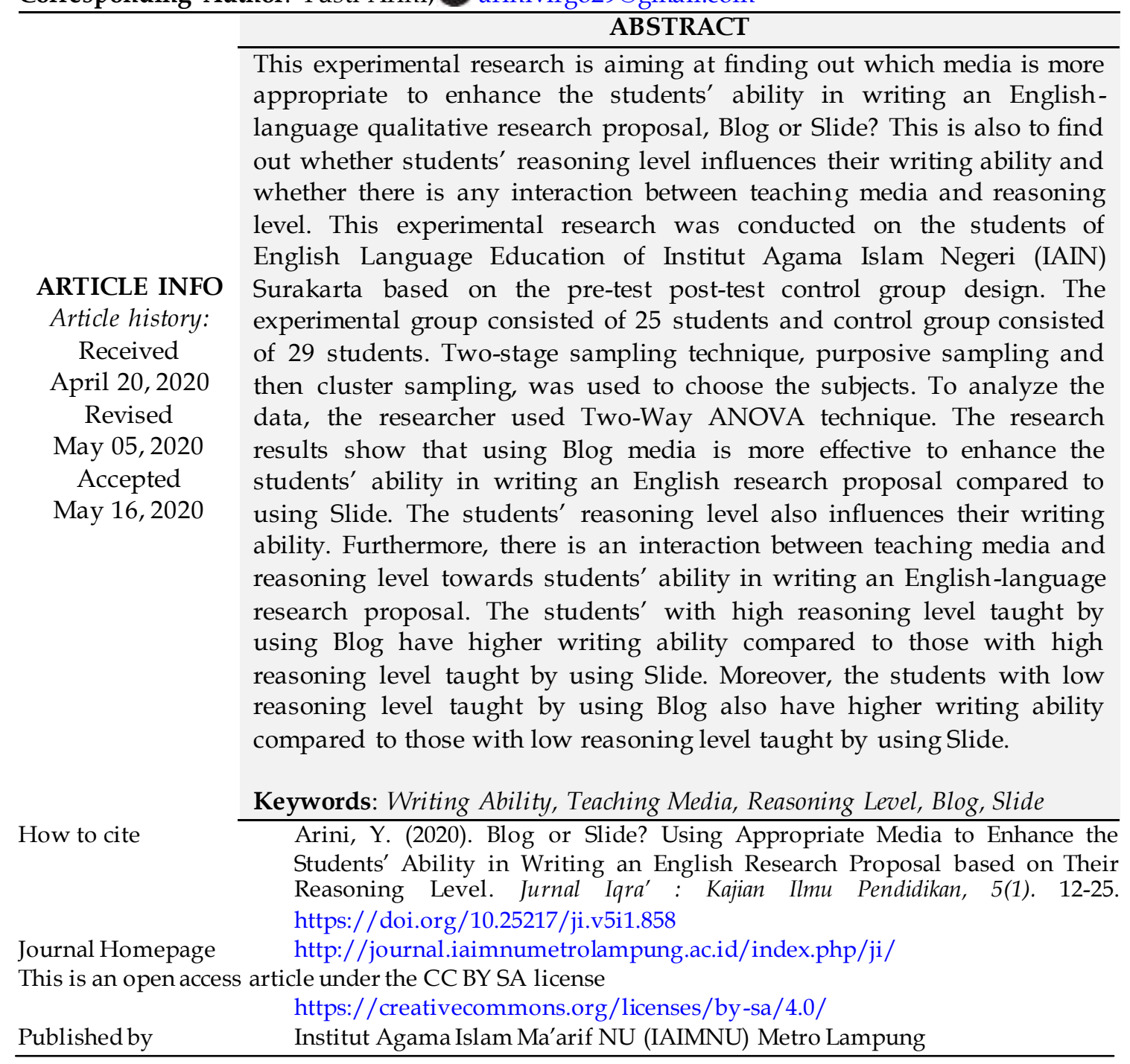

\section{INTRODUCTION}

In Indonesian context, writing is considered as painful activity indicating that oral culture is much better than writing one. The students' works sometimes cannot meet the expected criteria. Many research results show that there are a number of problems faced by learners when they have to complete reading and writing assignments in higher education (Alvarez, 2012; Lim \& Polio, 2020; Lei, 2016; McGrath et al., 2016; Philippakos, 2018; Rainey, 2017) 
Today, with the advancement of information and communication technology as well as the development of interactive and multimedia dynamics on websites and game-learning, new alternatives can be used to overcome problems faced by learners in the field of reading and writing (Vadia, 2018; Yusof \& Ismail, 2016; Vasilyeva, 2016). For example, the use and potential of blogs has extended to the tertiary context, including lecture materials that specifically focus on reading and writing skills.

This fact also happens in the higher education level. Most of the students still feel difficult to finish their writing tasks well. One of the abilities the students should master in writing is academic writing ability, among others, writing a research proposal. Meanwhile, the skill of writing a research proposal is classified as one of the writing skills derived from Process/Cognitive approach. Students need to integrate their abilities to come up with their ideas, do brainstorming about their topic with their classmates, write their task, and discuss the results with their friends. Several components should be involved in this process; one of which is media used by the lecturer.

Often, students face several problems in finishing their writing tasks. However, the lecturer can help their students improve the ability in writing by implementing learning media. Today, with advances in information and communication technologies (ICTs), and the constant development of interactive and multimedia dynamics on websites and e-learning platforms, new alternatives can be used to overcome students' reading and writing problems (Arwansyah et al., 2019; Alvarez, 2012; Harpiansi \& Suryani, 2019). The use and potential of blogs, for example, has spread to the university context, including subjects and courses that specifically focus on reading and writing skills (Yusof \& Ismail, 2016; Marvell, 2018; Fauzan, 2017). Further, writing skills means the knowledge of how to produce linguistically and pragmatically accurate sentences given particular sociocultural norms together with the ability to use strategies to allow effective communication" (Karlsson, 2014). From the perspective of writing skills, linguistic competence is the fundamental knowledge of vocabulary, grammar and mechanics. A writer needs to know the meaning of words and how to use them in different contexts as well as grammar rules, rules for punctuation and how to spell, to be able to form texts that are readable (Coxhead, 2018; Karlsson, 2014). Authentic readings help student learn to use grammar structures correctly because they include samples of what native speakers say. It is important for lecturers to keep in mind that the way they teach and the practice activities they implement in class will directly affect successful transfer of the skills to real-life situations (Hernández Herrero, 2011).

In the lecture process, one of the important external factors in the learning process is the media used by the lecturer. In order to improve the quality of learning so that students' abilities increase, lecturers are required to be able to provide alternative learning media that is appropriate in accordance with the expected skills and characteristics of students being taught. Meanwhile, in the application of media in the learning process, sometimes a 
number of problems arise. Problems related to the learning media include whether the learning media affect the writing ability of students, whether the lecturer can provide the right learning media, whether the learning media used can improve internal factors within students, and what learning media is appropriate for a variety of different situations and conditions.

Another factor that influences the learning process is the reasoning level. Reasoning skills are the capability to improve conceptual understanding and subsequently problem-solving skill among students (Arshad et al., 2017; Psycharis \& Kallia, 2017). Reasoning skills are very important in encouraging students to think more systematically, analytically, critically, and logically, as well as having the problem-solving skills, and ability to apply mathematical knowledge in real life (Naufal et al., 2017; Mustika et al., 2019; Arshad et al., 2017). This means that scientific reasoning is an analytical activity that uses scientific logic, and so is other reasoning that uses its own logic as well. Reasoning is an important process in mathematics work as well as other works. If the ability to reason is not developed in students, then for students mathematics and other works will only be material that follows a series of procedures and imitates examples without understanding their meaning (Murphy et al., 2017).

Furthermore, various problems arise in the learning process of Qualitative Research courses conducted at the English Language Education of IAIN Surakarta, especially in the process of preparing English language research proposals, allegedly related to the difficulty of students in mastering writing skills due to low grammar mastery, low vocabulary mastery, difficulty in finding ideas and pouring into written form, difficulty in connecting sentences to one another, difficulty in connecting one paragraph to another, and difficulty in editing and revising the concept of writing to become a final product of writing that is ready to read by audience. The students also feel difficult to find interesting topics to write in their research proposal which are closely related to the daily life and give many benefits for the readers. Due to this condition, it is quite difficult for the students to produce a good writing task as demanded in the previous theories explained above.

The study from Chawinga (2017) reported that if properly implemented, Twitter and Blogs can be a medium of interaction in the learning process that is learner-centered. By using this technology, students can share knowledge and discuss lecture materials, post reflections on lecture materials, and interact with friends and lecturers 24/7. Wheeler in Chawinga states that social media such as Twitter and Blog can be combined to make it easier for both students and lecturers to participate and communicate actively in educational activities. Alsubaie \& Madini (2018) declared that an improvement in the students' writing performance after using the blog entries. In addition, the research experiment contributed to the extension of their vocabulary knowledge. Results of a research conducted by Said et al., (2013) suggested that the participants have positive perceptions and attitude in using blog to improve writing skills and they perceived that blogging was an effective tool to teach writing in 
English that helped them improve their writing and kept them motivated.

Meanwhile, the research results conducted by Kohsamut \& Sucaromana (2017) revealed that students significantly performed better scores on English writing ability test after being taught through the blog. In addition, students showed positive views because using blog was very interesting and it provided more cooperation between teacher and students. While this current study aims to find out 1) difference in the ability to write English research proposals between group of students given media Blogs and those given Slide media, 2) the effect of interaction between learning media and the level of reasoning on the ability to write English research proposals for students, 3) difference in writing skills English-language research proposals between group of students given the Blog media and those given Slide media for the students with high level of reasoning, and 4) difference in the ability to write English-language research proposals between group of students given Blog media and those given Media Slide for the students with low reasoning level.

Compared to the previous studies explained above, this study is an experimental study that also involved several participants in the process of teaching writing. This study also uses Blog media to enhance the students' ability writing a research proposal. It can be said that this research has several similarities to those previous studies. However, several differences can be found in this research. This research compares the use of Blog media to the use of Slide media. The focus of the material in this study is academic writing, namely the ability of students to write research proposals in English. Reasoning skill level also becomes one of the variables investigated in this research. This research tries to find the interaction effect between learning media and reasoning skill level toward students' writing skill. Therefore, it can be clarified that this study involves more variables and more complex research design as well as data analysis. In short, this research is an expansion of the previous studies.

\section{METHODS}

This is an experimental research with pretest-posttest control group design, that is, an experiment giving pretest before applying treatment and posttest after treatment. The research variables constellation of this $2 \times 2$ factorial design is shown in Table 1.

Table 1. Research Variables Constellation

\begin{tabular}{ccc}
\hline & \multicolumn{2}{c}{ Learning Media $(\boldsymbol{A})$} \\
\cline { 2 - 3 } Reasoning Level $(\boldsymbol{B})$ & Blog Media $(\boldsymbol{A 1})$ & Slide Media $(\boldsymbol{A 2})$ \\
\hline High $(B 1)$ & $A 1 B 1$ & $A 2 B 1$ \\
\hline Low $(B 2)$ & $A 1 B 2$ & $A 2 B 2$ \\
\hline
\end{tabular}

This research was conducted at English Language Education of Institut Agama Islam Negeri (IAIN) Surakarta. Pretest was given once before the 
treatment, the treatment was conducted in 8 meetings in order to deliver the materials and to apply the learning media, and then, at the last meeting the researcher gave the posttest to the subjects. The population of this research consisted of the sixth semester students of English Language Education of IAIN Surakarta at even semester in the academic year of 2018/2019. The subjects were chosen by using two-stage sampling technique. The first stage was purposive sampling technique, that was, choosing all sixth semester students as sample because the Qualitative Research subject was taught in this semester. The second stage was cluster random sampling technique; $6 \mathrm{I}$ class consisting of 25 students was chosen as the experimental group and 6J class consisting of 29 students was chosen as the control group.

Data were collected by giving one pretest before treatment and one posttest after treatment for both groups, experimental as well as control group. The tests included the instruction to make an academic essay for pretest and a qualitative research proposal in English based on social field individually for posttest. To find out the validity of the test the researcher used expert judgment and to find its reliability the researcher used inter-rater reliability. Data of reasoning level was also found by giving a test adapted from a standardized test so that try out to find out its validity and reliability was not needed.

Data were analyzed by using Two-Way ANOVA (Analysis of Variance). Before ANOVA was used, pre-requisite test was applied to find out whether the data were normal or not (normality test by using Kolmogorov-Smirnov formula) and whether the data homogenous or not (homogeneity test by using Levene's test). Two-Way ANOVA was used to find out the main effect of learning media and reasoning level towards the students' ability in writing an English proposal, the interaction effect between learning media and reasoning level towards the students' ability in writing an English proposal, the simple effects of learning media and reasoning level towards the students' ability in writing an English-language research proposal.

\section{RESULT AND DISCUSSION}

After the data had been processed with descriptive statistics, then the prerequisite tests were carried out, including tests of normality and homogeneity of data. In this study, the data normality test was carried out on the scores of the assignment results in the form of compiling qualitative research proposals in English written by the students from all research groups using the Kolmogorov-Smirnov test. Based on the result of normality test calculation for all groups $(A 1, A 2, A 1 B 1, A 1 B 2, A 2 B 1$, and $A 2 B 2)$, a p-value of 0.673 was obtained, which means $\mathrm{p}$-value $>a=0.05$, so that $\mathrm{H}_{0}$ was accepted. This showed that all the data groups in this study came from normally distributed population. Thus the data normality requirement had been met.

Next, the variance homogeneity test was performed using the Levene's test. From the results of the Levene's test with statistics $F=0.135$ with $\mathrm{db} 1=3$ and $\mathrm{db} 2=50$, it was obtained that $\mathrm{p}$-value $=0.939>0.05$, so that the data of the six sample data groups had the same or homogeneous variance. One of the 
assumptions that must be met is that the six groups have homogeneous (equal) variance, in this case whether the dependent variable (the students' ability to write a qualitative English-language research proposal) of each sample group has the same variance or not. This is because differences in group mean values can only be meaningful if the group variance is homogeneous.

Based on the results of the test requirements for the hypothesis test (normality test and homogeneity test), it could be concluded that all data came from populations that were normally distributed and data from all groups had homogeneous population variance, so that hypothesis testing using Two-Way ANOVA (Analysis of Variance) could be done.

Hypothesis testing in this study used the Two-Way ANOVA (Analysis of Variance) technique, with the SPSS for Windows 22.0 program. This technique was used to determine the main effect of learning techniques on the students' ability to write English-language research proposals. In addition, this technique was also used to determine the effect of interaction between the two independent variables (learning media and the level of reasoning) on the students' ability to write English-language research proposals.

If an interaction effect existed, the results of the analysis using the TwoWay ANOVA technique were then further analyzed using the Tuckey Test to determine the simple effect formed by learning media factor and the level of reasoning. Based on the results of calculation using the Two-Way ANOVA technique with $A B A * B$ design, it can be presented the results of hypothesis testing as shown in Table 2.

Table 2. Summary of Calculation Results Using Two-Way ANOVA Technique

\begin{tabular}{lcrrrc}
\hline Variance Source & Db & Sum Square & Mean Square & F & Sig \\
\hline Factor $A$ & 1 & 1730.888 & 1730.888 & 23.080 & 0.000 \\
\hline Factor $B$ & 1 & 113.716 & 113.716 & 1.516 & 0.001 \\
\hline Interaction $A^{*} B$ & 1 & 12.952 & 12.952 & 0.173 & 0.002 \\
\hline Error & 50 & 3749.771 & 74.995 & & \\
\hline Total & 53 & 324389.000 & & & \\
\hline
\end{tabular}

Difference in the Ability to Write an English-Language Research Proposal between Group of Students Given Blog Media and Those Given Slide Media The first hypothesis tested is:

$\mathrm{H}_{0}: \mu_{A 1} \leq \mu_{A 2}$

$\mathrm{H}_{1}: \mu_{A 1}>\mu_{A 2}$

The first hypothesis testing was determined by looking for the main effect of the learning media $(A)$ toward students' ability in writing an Englishlanguage research proposal. Based on the results of the Two-Way ANOVA calculation as presented in Table 2, the value of $F=23.080$ with $p$-value $=0.000$ was obtained. Thus $\mathrm{p}$-value $=0.000<\alpha=0.05$, meaning that $\mathrm{H}_{0}$ was rejected and $\mathrm{H}_{1}$ was accepted. These results indicate that there is a significant difference in the ability to write qualitative research proposals in English between group 
of students given Blog media and group of students given Slide media. The calculation results show that the group of students who were given Blog media (group A1) had an average score of 82.92, while the group of students who were given Slide media (group A2) had an average score of 71.59.

Difference in the Ability to Write an English-Language Research Proposal between Group of Students with High Reasoning Level and Those with Low Reasoning Level

The second hypothesis tested is:

$\mathrm{H}_{0}: \mu_{A 1} \leq \mu_{A 2}$

$\mathrm{H}_{1}: \mu_{A 1}>\mu_{A 2}$

The second hypothesis testing was determined by looking for the main effect of the reasoning level $(B)$ toward students' ability in writing an Englishlanguage research proposal. Based on the results of the Two-Way ANOVA calculation as presented in Table 2 , the value of $F=1.516$ with $p$-value $=0.001$ was obtained. Thus $\mathrm{p}$-value $=0.001<\mathrm{a}=0.05$, meaning that $\mathrm{H}_{0}$ was rejected and $\mathrm{H}_{1}$ was accepted. These results indicate that there is a significant difference in the ability to write qualitative research proposals in English between group of students with high reasoning level and group of students with low reasoning level. The calculation results show that the group of students with high reasoning level (group B1) had an average score of 80.73 , while the group of students low reasoning level (group B2) had an average score of 72.54 .

Interaction Effect between Learning Media and Reasoning Level on the Students' Ability to Write English-language Research Proposal

The third hypothesis tested is:

$\mathrm{H}_{0}$ : Interaction $\mathrm{A} \times \mathrm{B}=0$

$\mathrm{H}_{1}$ : Interaction $\mathrm{A} \times \mathrm{B} \neq 0$

The third hypothesis testing was determined by looking for the effect of interaction between learning media $(A)$ and the level of reasoning $(B)$ on the students' ability to write English-language qualitative research proposal. Based on the results of the Two-Way ANOVA calculation as presented in Table 2, the Fo $(\mathrm{AB})$ value $=0.173$ with $\mathrm{p}$-value $=0.02$ was obtained. Thus $\mathrm{p}$-value $=0.02<$ $\mathrm{a}=0.05$; meaning that $\mathrm{H}_{0}$ was rejected and $\mathrm{H}_{1}$ was accepted; it can be concluded that there is an interaction effect between Factor $A$ and Factor $B(A$ * $B$ ) on the students' ability to write English-language qualitative research proposals.

Differences in the Ability to Write an English-Language Research Proposal between Group of Students Given Blog Media and those Given Slide Media for Students with High Reasoning Level

The fourth hypothesis tested is:

$$
\begin{array}{ll}
\mathrm{H}_{0} & : \mu_{A 1 B 1} \leq \mu_{A 2 B 1} \\
\mathrm{H}_{1} & : \mu_{A 1 B 1}>\mu_{A 2 B 1}
\end{array}
$$

The fourth hypothesis testing was determined by looking for the simple 
effect of the learning media $(A)$ and reasoning level $(B)$ toward students' ability in writing an English-language research proposal, specifically for the students with high reasoning level. Based on the results of the Two-Way ANOVA calculation, the value of $\mathrm{D}_{\mathrm{o}}=4.68$ at the significant level of $a=0.05$, meanwhile the value of $\mathrm{LSD}=3.45\left(\mathrm{D}_{\mathrm{o}}>\mathrm{LSD}\right)$; meaning that $\mathrm{H}_{0}$ was rejected and $\mathrm{H}_{1}$ was accepted. These results indicate that there is a significant difference in the ability to write qualitative research proposals in English between group of students given Blog media and group of students given Slide media, specifically for the students with high rational level $(A 1 B 1 \neq A 2 B 1)$. The calculation results show that the group of students with high reasoning level who were given Blog media (group A1B1) had an average score of 83.85, while the group of students with high reasoning level who were given Slide media (group A2B1) had an average score of $73.47(A 1 B 1>. A 2 B 1)$.

Difference in the Ability to Write an English-language Research Proposal between Groups of Students Given Blog Media and those Given Slide Media for Students with Low Reasoning Level

The fifth hypothesis tested is:

$$
\begin{array}{ll}
\mathrm{H}_{0} & : \mu_{A 1 B 2} \leq \mu_{A 2 B 2} \\
\mathrm{H}_{1} & : \mu_{A 1 B 2}>\mu_{A 2 B 2}
\end{array}
$$

The fifth hypothesis testing was determined by looking for the simple effect of the learning media $(A)$ and reasoning level $(B)$ toward students' ability in writing an English-language research proposal, specifically for the students with low reasoning level. Based on the results of the Two-Way ANOVA calculation, the value of $\mathrm{D}_{\mathrm{o}}=4.67$ at the significant level of $\mathrm{a}=0.05$, meanwhile the value of $\mathrm{LSD}=3.45\left(\mathrm{D}_{\mathrm{o}}>\mathrm{LSD}\right)$, meaning that $\mathrm{H}_{0}$ was rejected and $\mathrm{H}_{1}$ was accepted. These results indicate that the group of students with low reasoning level who were given Blog media $(A 1 B 2)$ had higher ability in writing an English-language qualitative research proposal compared to the students with low reasoning level who were given Slide media (A2B2). Moreover, the first group had an average score of 81.92 , while the second group had an average score of 73.59 (A1B1 > .A2B1).

Based on the results of the first hypothesis testing by using the Two-Way ANOVA technique, it is found out that there is a significant difference of the ability to write English-language qualitative research proposal between the group of students given Blog media and those given Slide media. This is indicated by the index of $\mathrm{F}_{\mathrm{o}}(A)$ which is 23.080 with $\mathrm{p}$-value $=0.000<0.05$, which means that $\mathrm{H}_{0}$ is rejected and $\mathrm{H}_{1}$ is accepted. The calculation results show that the group of students who were given Blog media (A1) had an average score of 82.92 , while the group of students who were given Slide media (A2) had an average score of 71.59. Based on these results, it can be concluded that there is a significant difference in the ability to write qualitative research proposals in English between group of students given Blog media and those given Slide media. The average scores show that the ability to write qualitative research proposal in English of the students given Blog media is higher than the 
students given Slide media; it means that the ability of students who were given Blog media is higher than those given Slide media.

The difference in abilities as described above is an indication that the provision of different learning media will affect the ability of students when combined with totally different learning techniques and with different students' characteristics. The average ability of the group of students who were given the Blog media was higher than the group of students who were given the Slide media, thus statistically the difference in the average scores could be the basis for concluding that there were significant difference in ability between the two groups of students.

In its implementation in real classroom, it could be seen that the provision of Blog media in Qualitative Research lecture made the students looked more enthusiastic in participating in the learning process. Students became more motivated to bring up their opinions and results of thought, and to give questions and suggestions for improvement to other groups through a class blog.

Meanwhile, group of students who were taught using Slide media tended to be more passive and only accepted presentation material from other groups without making the best effort to bring up their thoughts in the form of questions and suggestions for improvement. The presentation files that they made also tended to be very simple and less sharp in generating an interest of the audience to observe their materials. In the daily learning process, there was less enthusiasm from students so that the learning process also run less dynamically.

The strength of the Blog media is that it is more effective in stimulating the ability of students to come up with their ideas. This is because the media is more up to date and allows interaction between students outside of class time so that students have greater opportunities to express their ideas. However, in this study, the experimental group did not get preferential treatment compared to the control group, except for differences in learning media and techniques.

Based on the result of the second hypothesis testing using the Two-Way ANOVA technique, it is found out that there is an effect of the interaction between the learning media and the level of reasoning on the students' ability to write English-language qualitative research proposal. This is indicated by the index of $\mathrm{F}_{\mathrm{o}}(A B)$ which is 0.173 with $\mathrm{p}$-value $=0.680>0.05$, which means that $\mathrm{H}_{1}$ is accepted and $\mathrm{H}_{0}$ is rejected.

The existence of interaction effect between learning media and reasoning level on the students' ability in writing an English-language research proposal as described above is an indication that the provision of different learning media is related to the level of reasoning in influencing students' writing abilities. Observations in the classroom found that in Qualitative Research lecture students who seemed more active in participating in the learning process because they were given the Blog media and scored high on their writing tests were also very good at the reasoning test results. Meanwhile, students who were taught using Slide media seemed to have difficulty 
following the learning process so that the results of the writing test are low. They also achieved quite bad scores on the reasoning test or were included in the category of students with low reasoning level.

The existence of this interaction effect can be interpreted that the data supports the theory that the Blog media can open up opportunities for learners to further optimize their abilities because it can be used throughout the day without being limited to face-to-face meetings in the classroom. That the level of reasoning can affect learners' abilities is also supported by the research data.

Nevertheless, the calculation results show that specifically for students with high level of reasoning, the group of students who were given the Blog media (A1B1) had an average score of 83.85, while the group of students who were given the Slide media (A2B1) had an average score of 73.47. Based on these results it can be said that there is a difference in the average ability to write qualitative research proposal in English between group of students given Blog media and those given Slide media, specifically for the group of students with high level of reasoning. The results of this study imply that the ability of students with high level of reasoning in the group of students given Blog media were higher than the group of students given Slide media.

Furthermore, theoretically, students with high level of reasoning are relatively more adaptable to the use of any learning media. Moreover, the Blog media here is a medium that is quite up to date and interactive and can be used to publish their works. Through this publication students with high reasoning level will try to show their best work and always strive to actively share their thoughts with their classmates. Thus their writing skills are also trained and can eventually improve significantly.

Nevertheless, the calculation result show that specifically for students with low level of reasoning, the group of students given the Blog media (A1B2) had an average score of 81.92 , while the group of students given the Slide media (A2B2) had an average score 71.59. Specifically for the group of students with low reasoning level, the students given the Blog media have higher ability to write an English-language qualitative research proposal than students given the Slide media. These results imply that the provision of Blog media for students with low reasoning level can stimulate them to maximize their thinking capacity and there is encouragement to show their best abilities because their writing is uploaded to class blog where all people in the world can access it. Meanwhile, for students with low reasoning level, the use of Slide media will make them more comfortable because the results of their work are only observed by the lecturer and their class mates. This condition does not bring a strong encouragement for them to show their best abilities. There is even indication that they tend to rely on friends in their group to complete the assignments given by the lecturer.

From the results of all hypotheses testing, it can be concluded that the use of Blog media is appropriate for all reasoning level; high as well as low reasoning level. Blog media can improve the students' ability in writing an English research proposal for both groups; students with high reasoning level 
as well students with low reasoning level. Therefore, it can be said to be an appropriate media in teaching writing, one of which, teaching the academic or scientific writing. It can also be used as a training media for students to publish their works, although in a simple way. For lecturers, using Blog media will enable them to review the students' works all the time; not only in the classroom but also in any places.

The research results and discussion show several similarities to the results of previous studies in that the use of Blog media in Writing teaching learning process can improve the students' writing scores, can increase the students' motivation and enthusiasm, and leads a positive attitude toward the use of digital technology in the classroom. Meanwhile, compared to the results of previous studies Chawinga (2017) Alsubaie \& Madini (2018) Kohsamut \& Sucaromana (2017) Said et al., (2013), several differences also can be found. Because this research also used Slide media in control group, and integrated reasoning level in measuring the students' writing ability, it can be seen that different media will also have different effect to the students' with different reasoning level. In fact, Blog media can give optimum effect to the students with high reasoning level because students with high reasoning level tend to be more confident in sharing their work results using Blog media so that they can get more feedback from their friends to improve their writing. On the other hand, Slide media is more appropriate for the students with low reasoning level, because the use of Slide media does not demand the students to be highly sophisticated. By using this kind of media, not all people can read their work results and also their comments due to the limitation of its access. Only the students in the classroom who can read the work results and then give them feedback and questions orally. These facts cannot be found in the results of previous studies. Therefore, it can be said that the research results can enrich the results from previous studies.

The research results are expected to give some contributions to the lecturers, students, institution, and also other researchers. Knowing that using Blog media can increase the students' writing ability, especially in writing an English research proposal, the lecturers can also try to use this kind of media in their classroom. However, the use of this media should also be combined with appropriate techniques and learning duration. For the students, Blog media can be used to train them in publishing their writing; it is essential for there will be a higher demand of publication in the future. They should also realize that publishing their writing through Blog media can enhance the opportunity to get feedback from many people other than their friends. For the institution, the use of Blog media as a part of digital technology will encourage the institution to improve the facilities, give presentable records of the teaching learning process, as well as become a basis for taking policies in improving the quality of teaching learning process. Meanwhile, for other researchers, these research results can be basis for conducting other research with similar issue and also give references for them. 


\section{CONCLUSIONS}

Based on the results of hypothesis testing and discussion, the following conclusions are drawn: 1) there is a significant difference in the ability to write an English-language qualitative research proposal in the group of students given Blog media and the group of students given Slide media; the ability of students given Blog media is higher than those given Slide media, 2) there is a significant difference in the ability to write an English-language qualitative research proposal in the group of students with high reasoning level and the group of students with low reasoning level; the ability of students with high reasoning level is higher than those with low reasoning level, 3) there is an interaction effect between learning media and reasoning level on the students' ability to write an English-language qualitative research proposal, 4) specifically for the group of students with high reasoning levels, the students that are given Blog media have higher ability in writing an English-language research proposal than those given Slide media, and 5) specifically for the group of students with low reasoning levels, the students that are given Blog media have higher ability in writing an English-language research proposal than those given Slide media.

\section{ACKNOWLEDGMENTS}

This research was funded by the Budget Allocation of Institut Agama Islam Negeri (IAIN) Surakarta in the fiscal year of 2017 and stated in the Decree of the Rector of IAIN Surakarta Number 296 Year 2017. This research was categorized into Individual Research.

\section{AUTHOR CONTRIBUTION STATEMENTS}

The author had participated in the research and approved the final version of the manuscript

\section{REFERENCES}

Alsubaie, A., \& Madini, A. A. (2018). The Effect of Using Blogs to Enhance the Writing Skill of English Language Learners at a Saudi University. Global $\begin{array}{llll}\text { Journal of Educational Studies, } & 4(1),\end{array}$ https:/ / doi.org/10.5296/gjes.v4i1.12224

Alvarez, G. (2012). New Technologies in the University Context: The Use of Blogs for Developing Students' Reading and Writing Skills. RUSC. Revista de Universidad y Sociedad Del Conocimiento, 9(2), 185-199. https:/ / doi.org/10.7238/rusc.v9i2.1160

Arshad, M. N., Atan, N. A., Abdullah, A. H., Abu, M. S., \& Mokhtar, M. (2017). Improving the reasoning skills of students to overcome learning difficulties in additional Mathematics: a Review. Journal of Science and Mathematics Letters, 5, 28-35. Google Scholar

Arwansyah, Y. B., Widyaningsih, N., \& Daniswari, H. P. (2019). The Use of Edmodo-Based E-Learning Media in Improved Reading Interest with 
Blog or Slide? Using Appropriate Media to Enhance The Students' Ability in Writing an English Research Proposal based on Their Reasoning Level

Whole Language Approach. Journal of Physics: Conference Series, 1254, 012065. https:/ / doi.org/10.1088/1742-6596/1254/1/012065

Chawinga, W. D. (2017). Taking social media to a university classroom: teaching and learning using Twitter and blogs. International Journal of Educational Technology in Higher Education, 14(1). https:/ / doi.org/10.1186/s41239-017-0041-6

Coxhead, A. (2018). Vocabulary and Second Language Writing. In The TESOL Encyclopedia of English Language Teaching (pp. 1-6). American Cancer Society. https:/ / doi.org/10.1002/9781118784235.eelt0533

Fauzan, A. (2017). INCREASING STUDENTS' WRITING SKILLS BY UTILIZING BLOGS. LET: Linguistics, Literature and English Teaching Journal, 4(1), 38-49. https:/ / doi.org/10.18592/let.v4i1.1399

Harpiansi, H., \& Suryani, N. Y. (2019). Blended Learning in English Academic Reading to Respond Revolution 4.0. VELES Voices of English Language Education Society, 3(2), 145-153. Google Scholar

Hernández Herrero, A. (2011). Journals: A tool to improve students' writing skills. Actualidades Investigativas En Educación, 7(1). https:/ / doi.org/10.15517/ aie.v7i1.9241

Karlsson, A. (2014). How can blogging in foreign language education improve pupils writing skills? A research synthesis. Google Scholar

Kohsamut, T., \& Sucaromana, U. (2017). Using Blog To Enhance English Writing Skill. 3(2), 1337-1348. Google Scholar

Lei, X. (2016). Understanding writing strategy use from a sociocultural perspective: The case of skilled and less skilled writers. System, 60, 105116. https:/ / doi.org/10.1016/j.system.2016.06.006

Lim, J., \& Polio, C. (2020). Multimodal assignments in higher education: Implications for multimodal writing tasks for L2 writers. Journal of Second Language Writing, 47, 100713. https:/ / doi.org/10.1016/j.jslw.2020.100713

Marvell, A. (2018). Student experiences of facilitating knowledge exchange: Developing an understanding of responsible events through blog writing. Journal of Hospitality, Leisure, Sport E Tourism Education, 23, 1-9. https:/ / doi.org/10.1016/j.jhlste.2018.04.002

McGrath, L., Berggren, J., \& Mežek, Š. (2016). Reading EAP: Investigating high proficiency L2 university students' strategy use through reading blogs. Journal of English for Academic Purposes, 22, 152-164. https:// doi.org/10.1016/j.jeap.2016.03.003

Murphy, P. K., Firetto, C. M., \& Greene, J. A. (2017). Enriching Students' Scientific Thinking Through Relational Reasoning: Seeking Evidence in Texts, Tasks, and Talk. Educational Psychology Review, 29(1), 105-117. https:/ / doi.org/10.1007/s10648-016-9387-x

Mustika, M., Maknun, J., \& Feranie, S. (2019). Case study : analysis of senior high school students scientific creative, critical thinking and its correlation with their scientific reasoning skills on the sound concept. Journal of Physics: Conference Series, 1157, 032057. https:/ / doi.org/10.1088/1742-6596/1157/3/032057 
Naufal, M. A., Atan, N. A., Abdullah, A. H., \& Abu, M. S. (2017). Problem solving, based on metacognitive learning activities, to improve Mathematical reasoning skills of students. Man in India, 97(12), 213-220.

Philippakos, Z. A. (2018). Using a Task Analysis Process for Reading and Writing Assignments. The Reading Teacher, 72(1), 107-114. https:/ / doi.org/10.1002/ trtr.1690

Psycharis, S., \& Kallia, M. (2017). The effects of computer programming on high school students' reasoning skills and mathematical self-efficacy and problem solving. Instructional Science, 45(5), 583-602. https:/ / doi.org/10.1007/s11251-017-9421-5

Rainey, E. C. (2017). Disciplinary Literacy in English Language Arts: Exploring the Social and Problem-Based Nature of Literary Reading and Reasoning. Reading Research Quarterly, 52(1), 53-71. https:/ / doi.org/10.1002/rrq.154

Said, N. E. M., Yunus, M., Doring, L. K., Asmi, A., Aqilah, F., \& Li, L. K. S. (2013). Blogging to enhance writing skills: A survey of students' perception and attitude. Asian Social Science, 9(16 SPL), 95-101. https:/ / doi.org/10.5539/ass.v9n16p95

Vadia, M. N. (2018). Using Classroom Blog to Teach Writing to Senior High School Students. Journal of English Language Teaching, 7(1), 187-193-193.

Vasilyeva, N. N. (2016). The Use of Informational-communicational Technologies in Reading Difficulties Correction in Children. Procedia Social and Behavioral Sciences, 233, 292-296. https:/ / doi.org/10.1016/j.sbspro.2016.10.132

Yusof, F. H. M., \& Ismail, O. (2016). Writing Reflections Using Intranet WordPress Blog. In M. A. Abdullah, W. K. Yahya, N. Ramli, S. R. Mohamed, \& B. E. Ahmad (Eds.), Regional Conference on Science, Technology and Social Sciences (RCSTSS 2014) (pp. 945-955). Springer. https:/ / doi.org/10.1007/978-981-10-1458-1_85

First Publication Right :

(C) Jurnal Iqra' : Kajian Ilmu Pendidikan

This article is under:

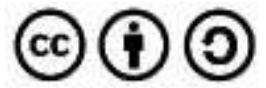

